\title{
Madrasah Headmaster Performance Strategy in Madrasah Al-Washliyah 22 Tembung
}

\author{
Ahmad Husin Siregar, Yusuf Hadijaya ${ }^{2}$ \\ ${ }^{1}$ Master Student of Islamic Education Management in FITK, UIN-SU, Indonesia \\ ${ }^{2}$ Lecturer in of Islamic Education Management in FITK, UIN-SU, Indonesia
}

\begin{abstract}
:
This study is to describe how the Strategy for Improving the Performance of Al-Washliyah Private Madrasah 22 Tembung. In Improving Performance of Al-Washliyah 22 Tembung. Madrasa Headmaster is a way to improve the quality of education and achieve educational goals. This type of research conducted is a type of qualitative research with naturalistic. Research data collection was obtained by collection techniques, interviews and documentation studies. The step of data analysis is to collect data, reduce data, present data and then collect data. To retrieve the validity data, a test of creativeness, transferability, dependability and confirmability was carried out. The findings of this study discussed three findings that discussed 1) Strategy for Improving the Performance of Madrasah Head in Al-Washliyah Madrasah 22 Tembung. 2) Madrasah Superintendent and Principal Development Policy at Al-Washliyah Madrasah 22 Tembung in Mapenda Area of the Provincial Ministry of Religion Office. 3) Implementation of Strategy Management for Madrasah Principals in Al-Washliyah Madrasah 22 Tembung. The results of this study were concluded as a Strategy for Improving the Performance of Headmaster at Al-Washliyah Madrasah 22 Tembung performed well and certainly there were still deficiencies that were not properly used properly.

Keywords :

strategy; performance; improvement
\end{abstract}

\section{Introduction}

Education is the most important means in developing human resources and the nation's character. Education is a process of transferring values and culture to individuals and society. The education process is located and developing along with the development process of human life. The problems that occur at this time do not rule out the possibility of education itself. Every education circles try to advance education especially in Indonesia. (Donni Juni Priansa, 2014: 42)

The madrasah head has an important role in coordinating, mobilizing, and aligning educational resources in the madrasah, because the madrasah head is one of the factors driving the achievement of madrasah vision and mission and bringing change in the educational institutions they lead. The success of an educational institution depends very much on the leadership of the madrasah head. Because the madrasah head as the leader in his institution, the madrasah head must be able to bring his institution toward the achievement of the goals set, madrasah head must be able to see changes, and be able to see the future in a better globalization life. The headmaster of the madrasah must be responsible for the smoothness and success of all matters of formal management and regulation to his superiors or informally to the community which has entrusted his students. The madrasah head is the functional teacher who is given the task to lead a madrasah as a place for the teaching and learning process or a place for interaction between the teacher giving the lesson and the students receiving the lesson.

In accordance with Yusnidar's research results (2014: 323) states that the head of the madrasah is a person who is responsible for carrying out educational activities in the madrasah and 
carry out activities in an effort to influence others in the environment in certain situations so that other people can work with a full sense of responsibility for achieving goals that have been set. The head of the madrasah is expected to be a strong, reliable and tested personal figure in the context of achieving the objectives of the madrasah. This is consistent with the results of Aninditya's research (2016: 18) which explains that the madrasah head is the most instrumental component in improving the quality of education and also the madrasah headmaster is a driving factor, determining the direction of madrasah policy that will determine how madrasa aims and education in general.

Estuary of the success of education one factor is on the shoulders of a madrasa head. As the manager of education, it is appropriate to have the willingness and ability in the form of performance as the head of the madrasah so that education is in the nuances of a pleasant learning process (enjoyful learning) and madrasah personnel enjoy more in carrying out their duties. Therefore, the headmaster is always required to increase the effectiveness of the performance of the staff in the madrasah. Seeing the importance and strategic position of the madrasa head in realizing the madrasa objectives, then the madrasah head should have the ability to establish good relations with all citizens in the madrasah, so that madrasah and educational goals can be achieved optimally, and the facts in the field that researchers note that the madrasa head has a good relationship both with the staff at the madrasa. The madrasah head is also a central figure in madrasah, a madrasah head is a person who is truly a leader, a manager, an educator and a supervisor.

\section{Literature Review}

Strategy is one of the tools to achieve goals. (Fred R. David, 2004: 15). Strategy is the process of determining the plans of top leaders who focus on the long-term goals of the organization, accompanied by the preparation of a way or effort on how to achieve these goals. While in general the strategy is an action that is incremental (constantly increasing) and continuous, and is carried out based on the perspective of what is expected by customers in the future. Thus, the strategy always starts from what can happen and not starts from what has already happened. The occurrence of new market innovation speeds and changes in consumer patterns requires Core Competencies. Companies need to find core competencies in the business they do. (Fred R. David, 2010: 19)

Job performance or performance comes from the word Job Performance, namely the work performance achieved by a person in carrying out the main tasks, functions and responsibilities given to him. Performance is also interpreted as the level or degree of implementation of one's tasks based on their competence. The term performance cannot be separated from work because performance is the result of work processes. In this context, the performance is the result of work in achieving a goal or job requirements that have been set. Performance can be interpreted as an expression of someone's potential in the form of behavior or the way someone in carrying out tasks, so as to produce a product (work results) which is a manifestation of all tasks and work responsibilities given to him. (Supardi, 2014: 45)

Performance can be shown by someone such as a madrasah teacher or headmaster or madrasah supervisor, it can also be demonstrated in certain work units or organizations such as madrasah, educational institutions, courses, etc. On that basis, performance is defined as the work achieved by a person or group of people in an organization according to their respective authorities and responsibilities in order to achieve the objectives of the organization concerned. This paper 
focuses on evaluating the performance of madrasah principals whose aim is to improve the performance of madrasah principals.

Madrasah head according to Wahjosumidjo in the book (Madrasah Leadership Leadership), madrasah head consists of two words, namely the head and madrasah. The head word can be interpreted as the chairman or leader in an organization or an institution. Where as a madrasah is an institution in which to receive and give lessons. Thus simply the headmaster can be defined as a functional teacher who is given the task to lead a madrasa where teaching and learning processes are held, or where there is interaction between the teacher giving the lesson and the student receiving the lesson. (Wahjosumidjo, 2002: 83).

Madrasah headmaster performance improvement strategies create schools that have a profile that is built on the integration of independence, innovation, and climate that is conducive for its citizens to develop motivation, creativity, and critical attitude. (Hadijaya, 2013: 221). In implementing education management the Minister of National Education issues regulations number 19 of 2017 concerning Standards for management of education by primary and secondary education units and number 19 of 2017 concerning standards of madrasah principals which include managerial competence, personality, supervision, entrepreneurship and social. (Permendiknas, 2017: 120).

Madrasah Supervisors are civil servant teachers who are appointed to madrasah supervisory positions (PP no 19, 2017: 32). Supervision is the activity of madrasah supervisors in compiling a supervision program, carrying out a supervisory program, evaluating the results of the program implementation, and carrying out teacher professional guidance and training. Government Regulation No. 19 of 2017 concerning teachers in Article 15 paragraph 3 states that teachers who are appointed to the supervisory positions of education units carry out the task of professional teacher guidance and training and supervisory duties. (PP no. 19, 2017: 12).

\section{Research Methodology}

The location of this research is at MAS Al-Washliyah 22 Tembung, Jl Besar Tembung No 78 Tembung. And the study was conducted for approximately three months, starting from November 9, 2017 until January 4, 2018.

Research conducted at MAS Al-Washliyah 22 Tembung to find out how the strategy to improve the performance of madrasah head in MAS Al-Washliyah 22 Tembung, by describing the findings of the study. The research approach aims to reveal the existing data field, and connect the cause and effect to something that exists at the time of the study with the aim of obtaining a reality picture of the Madrasah Head Performance Improvement Strategy in MAS Al-Washliyah 22 Tembung. After submitting permission to study with the madrasah like the madrasah head directly there was a positive response to conduct research. It was also seen that the madrasah teachers and principals had a strong sense of brotherhood at MAS Al-Washliyah 22 Tembung.

This research uses qualitative research, with a naturalistic approach. The term naturalistic indicates that the implementation of this training did occur naturally, in a normal situation which was good and not manipulated the conditions and conditions. Qualitative research shows self and meaningful characteristics as a whole object to a phenomenon to obtain the truth. The process of collecting data in this qualitative research is participatory and the researcher himself acts as a key instrument that must prepare himself to participate fully. For this reason, researchers are required to be able to follow the life patterns and behaviors of research objects, both conducting interviews 
and observations. Researchers must follow the flow of informants and not send informants to follow and adjust their views with researchers. Data sources are all things that can provide information about data. In this study the data source used by researchers is secondary data sources, secondary data obtained through various sources namely literature articles, and sites on the internet relating to the research conducted. Analysis is the core idea for carrying out "theorizing from the field" by collecting data that is strategically directed through the development of theory. In this study data were collected, grouped, reduced, interpreted, and conclusions drawn. To strengthen the validity of the data from the findings and to maintain the validity of the study, the researchers proceeded to four validation standards consisting of 1. Credibility. 2. Transferability. 3. Dependability. 4. Confirmability.

\section{Discussion}

The first findings of this study indicate that the MAS Al-Washliyah 22 Tembung head strategy is a metacognitive strategy through the implementation of this strategy the madrasa head is able to improve performance which can be seen from the number of MAS Al-Washliyah 22 Tembung students each year increasing, in terms of the number of students and the number of pupils graduated from state universities.

The existence of the role and function of the madrasa head is one of the factors that determine the quality of the madrasah. In every effort to improve the quality of education, it cannot be separated from various matters relating to the existence of the madrasa headmaster. Madrasah head as the highest leader in the school, the pattern of leadership will be very influential even very determine the progress of the madrasah. Therefore, in modern education the leadership of the madrasah head needs to get serious attention. Madrasah Head Leadership is a way or effort of Madrasah Head in influencing, encouraging, guiding, directing and mobilizing teachers, staff, students, parents of students and other parties concerned to work / participate in achieving the stated goals

Madrasah head performance improvement strategies create madrassas that have a profile that is built on the cohesion of independence, innovation, and climate that is conducive for its citizens to develop motivation, creativity, and critical attitude. (Hadijaya, 2013: 221). This is in line with the opinion of Yusnidar (2014: 331) who said that the strategy to improve the performance of madrasah principals is an activity of changing individual behavior from good to better to achieve the organizational goals set can be achieved effectively and efficiently. And how the figure of the madrasah head will lead the unit works well if it is not competent in its field. For this reason, it is very necessary for the school principal to be able to lead well, therefore the madrasa head must be able to play the role of Educator, Manager, Administrator, Supervisor and Leader. This is in line with the opinion of Yusnidar (2014: 329) who said that the main role of the headmaster is, as follows "(1) Educator (educator), (2) Manager, (3) Administrator, (4) Supervisor).

Research results conducted by researchers at MAS Al-Washliyah 22 Tembung that madrasa heads have performed their roles as leaders such as educators by creating a conducive madrasa climate, giving advice to madrasah residents, giving encouragement to all education personnel, and implementing an interesting learning model, and then also as a manager carried out by the headmaster of madrasah in madrasah such as planning, organizing, implementing, leading and controlling the efforts of members of the organization and making use of all organizational resources to achieve the goals set. 
As the madrasah chief administrator, he has carried out roles such as managing the curriculum, managing the administration of records and financial administration. Then the madrasa head also has a role as a supervisor such as supervising the teaching and learning process of the teachers in the class and also other processes in the madrasah and then finally the madrasah head has also performed his role as a leader such as the ability to make decisions by always meeting without one party and the ability to communicate active with teachers in the village. This is in accordance with the results of Annisa's research (2016: 25) which states that the head of the madrasah acts as a leader, a leader who continues to do well so that he becomes a role model emulated by his subordinates.

From the results of research conducted by researchers at MAS Al-Washliyah 22 Tembung that the improvement in performance that has been carried out by the headmaster of madrasa both increases teacher performance and the performance of the headmaster themselves. And performance improvement for teachers carried out by the headmaster of madrasa is by increasing teacher competency through skills-based training, increasing teacher competency through information technology-based training and curriculum training 2013. That what is done by the madrasah head himself to improve his performance as madrasah head by increasing his abilities as an Educator, Manager, Administrator, Supervisor and also Leader.

The second finding shows that Supervision in madrassas is carried out well by the madrasa head as leader and also madrasah supervisors from the ministry of religion. the main purpose and function of ensuring the quality of education feel the need to make efforts to improve and increase the competence and professionalism of educators and madrasah principals. One effort that can be done by supervisors in this case is to conduct more intense academic supervision. It is believed that the intensity of the implementation of academic supervision by the supervisor of the madrasah headmasters and teachers in the fostered mentors will greatly affect the quality of learning. The higher the intensity of academic supervision by supervisors to the headmaster and teachers, the more likely the quality of learning will increase, and vice versa, the lower the intensity of academic supervision, the lower the quality of learning created in supervisory madrasah.

Supervisor is a process of observing the performance of someone to see whether certain activities are in accordance with the provisions, while the supervisor of the madrasah is an activity that conducts assessments and guidance by carrying out supervisory functions, both academic and managerial supervision. This is in accordance with the results of research Sudjana (2011:25) which states that Madrasah supervisors function as education Supervisors with the task of carrying out supervision or supervision namely academic supervision and managerial supervision.

In connection with the goals of academic supervision, Madrasah supervisors have the task of mentoring and helping to improve teacher performance to enhance the quality of student learning processes and outcomes. In carrying out managerial supervisory duties, the madrasah supervisor helps the madrasah head and madrasah staff to try to improve the quality of education delivery services in each madrasah that it builds.

From the results of research conducted by researchers at MAS Al-Washliyah 22 Tembung that the supervision in MAS Al-Washliyah 22 Tembung was carried out by the madrasah supervisors themselves namely the madrasah supervisors from the Ministry of Religion and also carried out by the madrasah head also. In this case, the results of research show that madrasah supervisors from the Ministry of Education supervise the teaching and learning process of teachers in Madrasah and also supervise the performance of madrasah principals by conducting interviews with teachers in Madrasah and even conducting direct interviews with Madrasah leaders 
themselves. If there is a discrepancy with the performance of the madrasa head, the madrasah supervisor from the Ministry of Education meets with the madrasah head and also the teachers then develops it by conducting training on the madrasah head performance.

This is consistent with the results of Afrizen's research (2016: 81) stating that given the strategic role of the madrasah head in the success of the education process, the madrasah head needs to receive guidance, guidance and coaching through the managerial supervision efforts of madrasah supervisors. This is also in accordance with the results of Sudjana's research (2012: 133) that coaching and enhancing the competency of madrasah principals is the most important part of managerial supervision carried out by madrasah supervisors.

Therefore managerial supervision is carried out by the madrasah supervisor as the education supervisor to the madrasah head in order to increase the ability for the madrasah head to carry out his main duties and functions and responsibilities. Whereas the supervision carried out by the madrasah head is to oversee all activities in the madrasa itself. If there are mistakes that are not appropriate, the madrasah head conducts reprimand and advice personally to the teacher concerned and even conducts meetings with the teachers at the madrasah.

The findings of these three studies show that the implementation of strategic management is carried out by the head madarasah to improve the quality of madrasah and also the performance of educators in madrasah. And in the aspect of strategy evaluation carried out by the headmaster of madrasah Al-Washliyah 22 Tembungis to conduct evaluations in various planning items by always holding control. The way to do this is to monitor the development and improvement of the competencies of teachers who have received education and training on a regular basis. In addition, an evaluation is carried out on each program of activities that have been carried out.

Strategy management is an important manager's task that is closely related to the basic functions of management. Furthermore, Ulfa (2014: 61) explains that strategic management is a systematic approach to a management's responsibility, conditioning the organization to a position that ensures achieving organizational goals. The first reason for the importance of strategy management is that strategy management can distinguish how well an organization is in achieving its performance.

The implementation of strategy management by the madrasah head in aligning the organizational structure is done carefully by involving teachers and employees to describe the fields and details of work, so as not to cause work tension in the madrasah environment. From the statement above, Usman (2013: 234) states that the success of an organization in providing services is largely determined by the factors that influence it, namely: (a) organizational characteristics, (b) environmental characteristics, (c) employee characteristics, and (d) management policies and practices, and are also strongly supported by the vision and mission of effective leadership, a dynamic governing body, and a weighted development program.

A fundamental question about strategy is why a company is successful or fails, or why when faced with the same environment, the company shows a different level of performance. Research on the factors that affect company performance shows a positive relationship between strategy management and performance. In other words, it turns out that companies that use strategy management will obtain a higher level of performance.

The description above explains that strategy management is management that is related to efforts to decide on the issue of strategy, planning, and how the strategy can be implemented in 
an implementative form. From the description it is clear that an organization should be able to implement the concepts of strategy management in the education and learning environment. Because basically management strategy aims to have high productivity so that organizational goals are achieved effectively.

Research results conducted by researchers at MAS Al-Washliyah 22 Tembung that the head of the madrasah implements the process of management in the madrasah like planning in advance before doing anything at the madrasa, even the madrasah head makes a swot analysis of the plans to be carried out in the madrasah. The results of the research in the field showed that the headmaster of madrasah also conducted trainings to teachers to improve teacher performance at MAS Al-Washliyah 22 Tembung.

\section{Conclusion}

In making a program, the madrasah head always involves all teachers and staff in the madrasah environment. In the implementation of each program, the madrasah head tries to give motivation, guidance and give appreciation in the form of gratitude for the work of the teachers, able to evaluate the work of teachers, supervising and directing in various activities related to the duties of the teacher and all activities - activities in madrasah in order to manage the quality of teaching staff. The strategy of developing supervisors and Madrasah Aliyah Principals applied is a mediative strategy, which is a strategy in the field of education where supervisors and Madrasah Aliyah principals learn through interactions designed by the Head of Mapenda as their supervisor so that the personnel are able to learn how to apply various knowledge and competencies to solving problems, conducting internal and external analysis, making alternative steps to anticipate if a plan does not go according to its performance standards, and encouraging and facilitating innovative and creative steps needed for madrasah progress.

Management strategies applied by the headmaster of Madrasah Al-Washliyah 22 Tembung as a manager, as expressed by E. Mulyasa (2005: 105) which says that managers are those who plan, organize, carry out, lead and control the business of their members and utilize all resources organization in order to achieve the goals set. In this case the headmaster has performed his role as a manager by utilizing teaching staff through cooperation, giving teachers the opportunity to improve their profession and encouraging the involvement of all teaching staff in various activities that support the madrasah program. Then it can be concluded that MAS Al-Washliyah 22 Tembung strategy is a metacognitive strategy through the implementation of this strategy through the role of supervisors as supervisors, madrasah principals as executives and teachers as educators.

\section{References}

David, Fred R. Strategic Management Manajemen Strategis Konsep. Jakarta: Salemba Empat, 2010. Hadijaya. Menyusun Strategi Berbuah Kinerja Pendidik Efektif. Medan: Perdana Publishing, 2013. Hadi, M. Strategi Kepala Madrasab DalamMeningkatkan Mutu Pendidikan Pada Min Buengcala Kecamatan Kuta Baro Kab Aceh Besar, Volume IV Nomor 02, 2014.

Hafied Cangara.Perencanaan dan Strategi Komunikasi. Jakarta: Raja Grafindo Persada, 2013.

Irani z, Ulfa. Implementasi Manajemen Strategi, volume 4, 2014.

Maulida, Annisa. Peran Kepala Sekolab Sebagai Manajer Dalam Meningkatkan Profesionalisme Guru PaiDi Smp It Nur Hidayah Surakarta, 2016.

Permendiknas. Standar Kepala Madrasah. Jakarta: Kementerian Pendidikan Nasional, 2017.

Supardi, Kinerja Guru. Jakarta: Raja Grafindo Persada, 2014.

ThomasJ, Wheelen dan David, Hunger J.Manajemen strategi. New Jersey: Prentice Hall, 1998. Wahjosumidjo. Kepemimpinan Kepala Sekolah. Jakarta: PT Raja Grafindo Persada, 2002. 